【原著】

\title{
つつみ込む気流制御エアコンの健常女性における健康維持 および疲労に対する有用性 \\ Effect of Enveloping-airflow Air Conditioner on Health Maintenance and Fatigue in Healthy Women
}

西谷真人 ${ }^{1, *}$ ，白市幸茂 ${ }^{2}$ ，大塚雅生 ${ }^{2}$ ，青柳さやか ${ }^{3}$ ，杉野友啓 ${ }^{3}$ ，梶本佳孝 ${ }^{3}$ ，梶本修身 ${ }^{4}$ Masahito NISHITANI ${ }^{1, *}$, Yukishige SHIRAICHI ${ }^{2}$, Masaki OHTSUKA ${ }^{2}$, Sayaka AOYAGI ${ }^{3}$, Tomohiro SUGINO ${ }^{3}$, Yoshitaka KAJIMOTO ${ }^{3}$, Osami KAJIMOTO ${ }^{4}$

\author{
1 総医研クリニック \\ 2 シャープ株式会社 \\ ${ }^{3}$ 株式会社総合医科学研究所 \\ ${ }^{4}$ 大阪市立大学大学院医学研究科
}

【要 旨】

本研究では，つつみ込む気流制御エアコンの 健康維持および疲労に対する有用性を検証す るため, 健常女性を対象としたランダム化 2 試験区クロスオーバー試験を実施した. エア コン使用時に冷えを感じやすい女性 10 名に, 2 時間のデスクワークによる疲労負荷を与え た後,つつみ込む気流または人あて気流でエ アコン制御された部屋で 30 分間休息させた. Visual Analogue Scale (VAS) による主観評 価, レーザ・ドップラ式血流計による血流測 定，および体温測定を実施した結果，つつみ 込む気流制御エアコンでの休息は，体温低下 を抑制し，末梢血流を維持することにより， 末梢の冷えおよび膝関節の疼痛を抑制し, 疲 労感の軽減および快適感の上昇を促進するこ とが明らかとなった. 本研究により，つつみ 込む気流制御エアコンの健康維持および疲労 に対する有用性が示された.

【キーワード】

つつみ込む気流, エアコン, 健康維持, 疲労, 冷え
はじめに

暑さ，寒さにかかわる温熱環境は，健康を損なら危険 性のある過度のストレスを及ぼすと考兄られる，温熱環 境には温熱 4 要素といわ的る気温, 湿度, 気流, 熱放射 が複合的に影響を及ぼしており，これらを冷暖房などで 適切にコントロールすることは健康維持のみならず，作 業効率や休息の質を向上させる上で重要であり, 疲労軽 減にも大きく関与すると考兄られる。

厚生労働省が 2002 年度に実施した労働者健康状況調 查によると，「普段の仕事で疲れる」とする労働者は 72.2 \%にのぼることが確認された ${ }^{11}$ 。現代の日本では冷暖房 の制御されたオフィスビルで勤務する労働者も多く, 温 熱環境が疲労に及湆す影響は大きい。また労㗢衛生面以 外でも温熱環境は重要であるが，現代の生活でも適切に 整備されているとはいえず，冷暖房が逆にストレスと なっている場合もある．冷房エアコンの冷風が身体に直 接あたって不快感をもたらし，冷え性，膝の痛及，肩こ りなどを引き起こす場合もあり，この症状は女性に多く みられる傾向にある。

本試験では，温熱 4 要素のひとつである気流を制御し た冷房エアコンの健常女性に打ける健康維持扣よび疲労 に対する有用性を検証した。

受理日：2009 年 1 月 13 日

* 干560-0082 大阪府豊中市新千里東町 1-4-2 ライフサイエンスセンター3 階 総医研クリニック Tel: 06-6871-8845 Fax: 06-6871-8865 E-mail: nishitani@soiken.com 


\section{材料. 方法}

\section{1. 対 象}

対象となる被験者は，(株）総合医科学研究所が公募し た有償ボランティアである．対象の選定にあたっては， （株）総合医科学研究所の「未治療被験者データバンク」 に登録された一般成人のなかから，本試験の被験者とな ることを自発的に志願し, 総医研クリニックで診察を受 け，本試験の内容について十分な説明を受け，別途定め る被験者の同意書により本試験参加の同意をする 20 歳 以上 65 歳未満の健常成人 10 名 (エアコン使用時に冷え, 膝の痛み，肩こりを感じやすい女性）とした。重篤な疾 患に罹患中の者や, 予備検査結果に異常值を認めたなど の理由から試験責任医師により参加が不適当と判断され た者は除外した.

この 10 名を, 試験データの解析に参加しない割付け担 当者がランダムに 2 群に割付けた。 このとき，割付け担 当者は，年齢，Body Mass Index (BMI) に拈いて 2 群間に 有意な差がないことを確認したらえでその割付け結果を 採択した。

な拈, 本試験は, 総合医科学研究所及び総医研クリニッ ク合同審査委員会（委員長 井上昌治弁護士）の承認の もとに行われ，ヘルシンキ宣言の主旨に従い，被験者に 対しては研究内容, 方法などについて医師より十分な説 明を行い実施した。

\section{2. 試験機器}

試験機器は, KIREION キレイオン (AY-W22SX, シャー プ (株) ) を用い，「つつみ込む気流（KIREION 気流）」 と,「人あて気流 (対照)」の 2 種類の気流で 2 試験区を 設定した.

\section{3. 試験デザイン}

試験の流れを図 1 に示した。試験はランダム化 2 試験 区クロスオーバー試験とし，2008 年 6 月 28 日〜 月 29 日に実施した。試験期間は，3 日間の前観察期間と検査 日 1 日を 1 試験区として設定し，これを 4 週間隔で 2 試 験区（つつみ込む気流扎よび人あて気流）繰り返した. 2 回の検査日に拈いて，2 時間のデスクワークによる疲労 負荷後, 気流制御されたエアコンルームで 30 分間, 椅子 に座って休息してもらった. エアコンルームにおける試 験機器の設定は, 温度を $24^{\circ} \mathrm{C}$, 風量を強風とし, リモコ ンの上下風向設定にてつつ夕込む気流と人あて気流の制 御を行った. エアコンルーム外の目標設定室温は 26.0 $27.0^{\circ} \mathrm{C}$ とた。
A

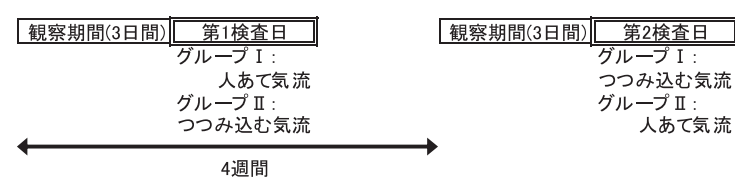

B

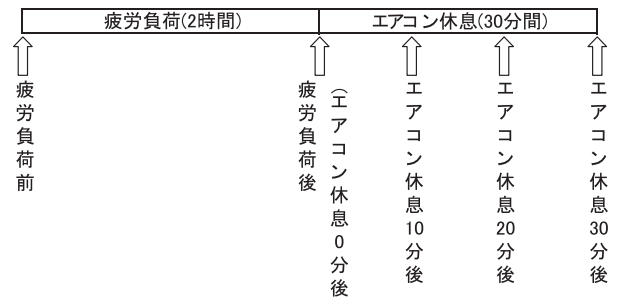

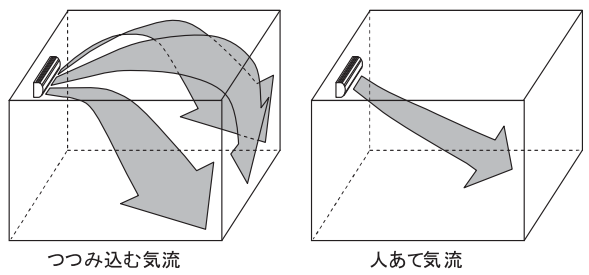

図 1 試験の流れ

A: 試験全体の流れ，B: 検査日の流れ

\section{4. 疲労負荷の方法}

疲労負荷の方法として, 紙面上での単純な足し算作業 である内田クレペリン検査 ${ }^{2}$ ，执よびパソコンでの探索 作業である Advanced Trail Making Test (ATMT) ${ }^{3)}$ を交互 に 30 分間 2 回ずつ, 合計2時間実施した. ATMT は, A 〜 Z でのアルファベットのらち 25 文字をパソコン画 面上にランダムに表示させ，「R」をクリックするたびに 配置が変わる設定とし，「R」を素早くクリックする視覚 探索反応課題とした.

\section{5. 検査方法}

下記の検査を実施した．生活状況調査を除くすべての 検査は，総医研クリニックにおいて医師の管理のもとに 実施した。

i. VAS 検査

疲労負荷前，疲労負荷 2 時間後，エアコン休息 10 分, 20 分，30 分後に主観的評価である VAS 検査 ${ }^{4)}$ を実施し た. 評価項目は疲労感，冷え，快適感，膝の痛み，肩こ りとした. エアコン休息開始後の検査はエアコンルーム 内にて実施した。

ii. 血流測定

エアコン休息 0 分, 10 分, 20 分, 30 分後にエアコン ルーム内にて測定した.レーザ・ドップラ式血流計 (Moor LDI, Moor Instruments) により，座位での両足の足首から 
つま先までの血流を測定した。

iii. 歩行速度測定

疲労負荷 2 時間後, エアコン休息 30 分後に $10 \mathrm{~m}$ の距 離をできる限り速く歩いてもらい，その間の歩行時間お よび歩数より歩行速度, 歩行率, 重複歩距離を算出した ${ }^{5)}$. iv. 生化学的検査

疲労負荷前, 疲労負荷 2 時間後, エアコン休息 30 分後 に唾液を採取した。 アミラーゼをC Caraway 法，コルチ ゾールをELISA 法, 総タンパクを Bradford 法により大阪 市立大学大学院医学研究科 COE 生体情報解析学に拈い て，クロモグラニンA を ELISA 法により（株）矢内原 研究所に拈いて測定した.

また，エアコン休息 30 分後の随時尿を全量採取した. クレアチニンを酵素法, バニルマンデル酸扣よびホモバ ニリン酸をHPLCにより（株）エスアールエルに打いて， 8-イソプラスタン拈よび8-ヒドロキシデオキシグアノシ ン $(8-\mathrm{OHdG})$ をLLISA 法により大阪市立大学大学院医学 研究科 COE 生体情報解析学に扑いて測定した.

v. 理学的検査

疲労負荷前, 疲労負荷 2 時間後, エアコン休息 30 分後 に血圧, 脈拍, 体温の測定を, 疲労負荷前に体重の測定 を実施した。

vi. 生活状況調査

前観察期間中毎日，睡眠時間，就業時間，運動量（万 歩計による歩数計測), 食事内容, 体調等を被験者各自に 日誌形式で記録させた。アルコール摂取量および医薬品 の使用状況については，試験期間中毎日記録させた。被 験者にはそれまでの食生活および運動などの日常生活を 大きく変えないよらに指示した. な报, 食事をコントロー ルするため, 検査前日の夕食は同一の宅配弁当（約 $900 \mathrm{kcal}$ ) を摂取させ，その後は来院まで絶食とし，疲労 負荷前の各検査後に同一の颃にぎり（約 $360 \mathrm{kcal}$ ）を摂
取させた。

vii. 温湿度の記録

エアコンルーム内外の温湿度を 30 分間隔で記録した. viii. 診察・問診

疲労負荷前に診察・問診を行い, 自覚症状および他覚 所見の発現状況を把握した. その際の問診の仕方には十 分注意し，客観的な評価を行った。

\section{6. 統計解析}

すべての計量值データについて, SPSS version 11.5 (エ ス・ピー・エス・エス (株)）による統計解析を使用し， 対応のある $\mathrm{t}$ 検定により群間比較を行った.さらに VAS 検査扎よび血流については, 反復測定 ANOVA 実施後, Bonferroni 法による多重比較検定を実施し経時的変化に ついて解析した. 両側検定で $\mathrm{p}<0.05$ を統計学的に有意と した。

\section{結 果}

第 1 検査日の疲労負荷後（エアコンルーム入室前）に 気分不良を起こした 1 名を除外したため，最終的に解析 の対象となった被験者数は9 名となった. 被験者の流れ のフローチャートを図 2 に示した. 被験者 9 名の年齢, BMI の平均值士標準偏差は 48.0 \pm 9.3 歳, $21.6 \pm 1.9 \mathrm{~kg} / \mathrm{m}^{2}$ て あり, 割付け後の各群間でそれらの項目において有意差 は認められなかった。

\section{VAS 検査}

結果を図 3 に示した. つつ久込む気流群は人あて気流 群と比較して, エアコン休息 10 分, 20 分, 30 分後にお いて疲労感の有意な軽減, 冷えの有意な抑制, 快適感の 有意な上昇が認められ, エアコン休息 30 分後に抏いて膝

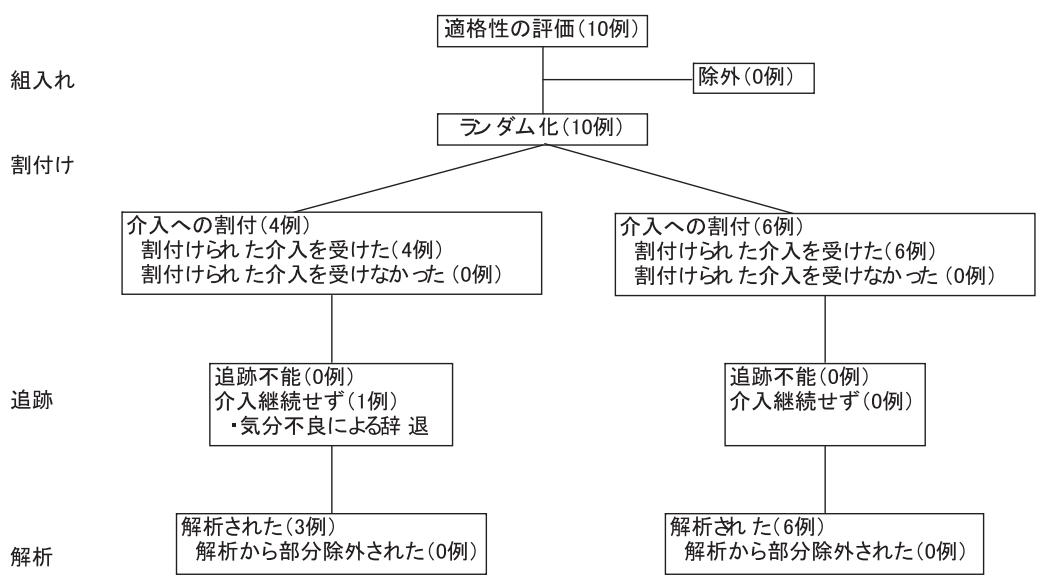

図 2 各段階での被験者の流れを示すフローチャート 
A

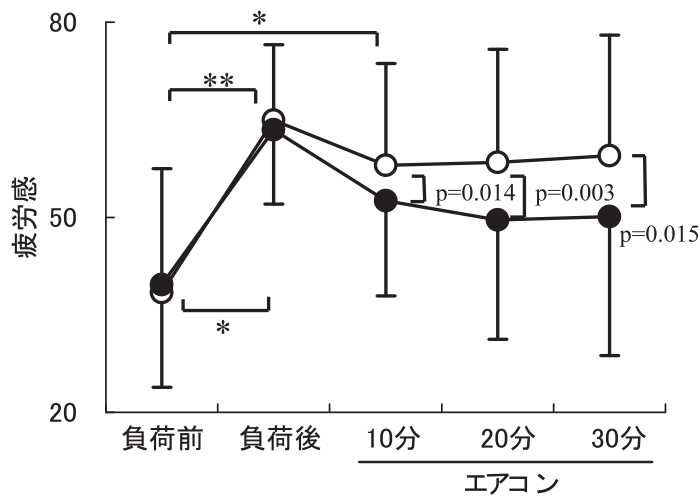

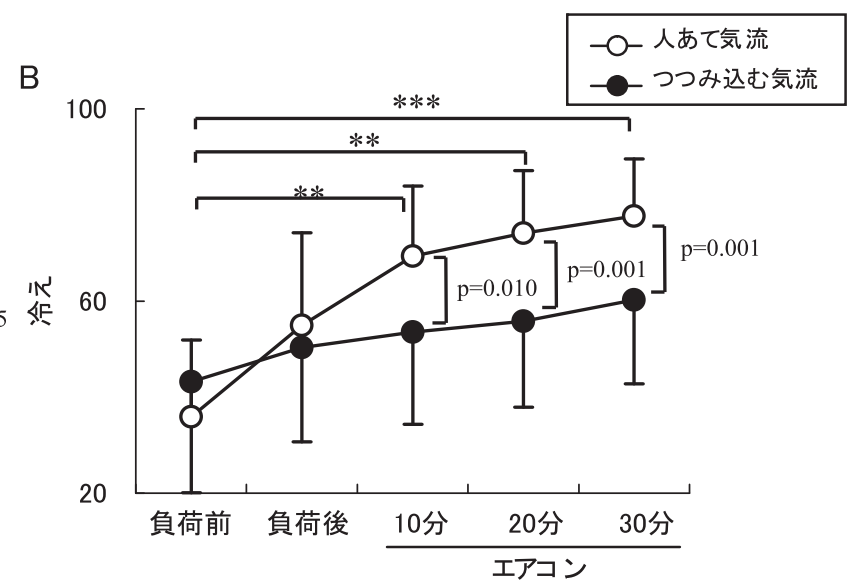

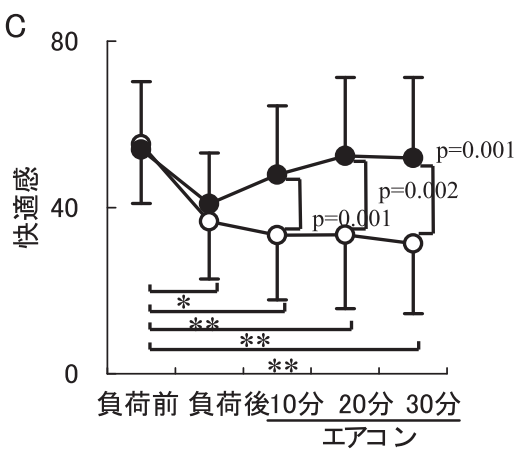

D 80

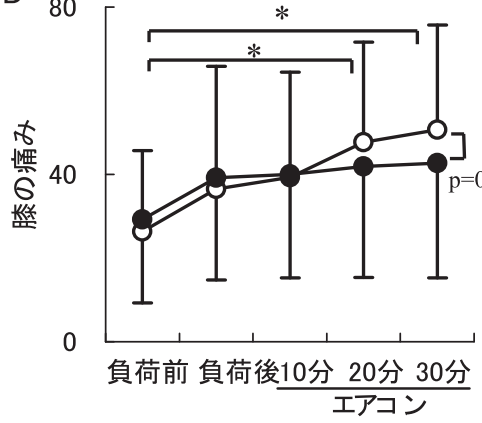

E 100

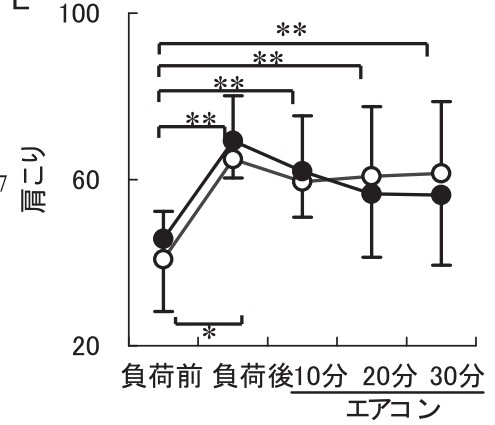

图 3 VAS に上る主観的評価

縦軸はVAS スコアを 0:「最良の感覚」, 100:「最悪の感覚」（快適感については 0:「最悪の感覚」, 100:「最良の感覚」）として, 平均值 土標準偏差を示した．図中の $\mathrm{p}$ 值は対応のある $\mathrm{t}$ 検定による. *印は Bonferroni 法による多重比較検定結果 (***: $\mathrm{p}<0.001, * *: \mathrm{p}<0.01$, *: $\mathrm{p}<0.05)$.

の痛みの有意な抑制が認められた，疲労負荷前値と比較 した経時的変化については, 人あて気流群ではエアコン 休息 10 分， 20 分，30 分後に扣いて冷兄打よび肩こりの 有意な上昇, 快適感の有意な低下, エアコン休息 20 分, 30 分後において膝の痛みの有意な上昇, エアコン休息 10 分後に打いて疲労感の有意な上昇が認められた一方で, つつ久込む気流群ではそれらの変化は認められなかっ た.

\section{2. 血流測定}

結果を図 4,5 に示した。つつみ込む気流群は人あて気 流群と比較して, エアコン休息 10 分, 20 分, 30 分後に おいて血流の有意な低下抑制が認められた。疲労負荷後 （エアコン休息 0 分後）と比較した経時的変化について は，人あて気流群ではェアコン休息 10 分，20 分後にお いて血流の有意な低下が認められた一方で，つつ久込む 気流群では変化が認められなかった。

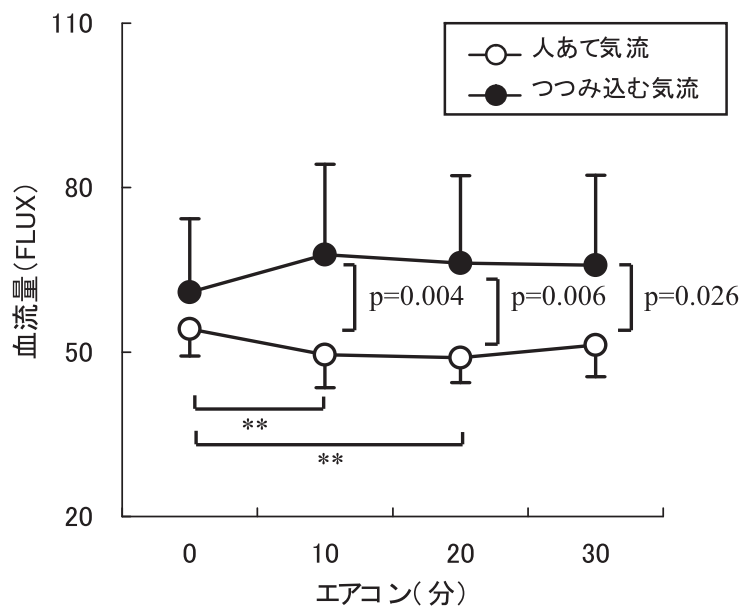

図 4 レーザ・ドップラ式血流計による血流測定 平均值土標準偏差を示した. 図中の $\mathrm{p}$ 值は対応のある $\mathrm{t}$ 検定に よる. *印は Bonferroni 法による多重比較検定結果 $(* *$ : $\mathrm{p}<0.01)$.

\section{3. 歩行速度測定}

結果を表 1 亿示した. つつ久込む気流群は人あて気流 群と比較して有意な差は認められなかったが，エアコン 


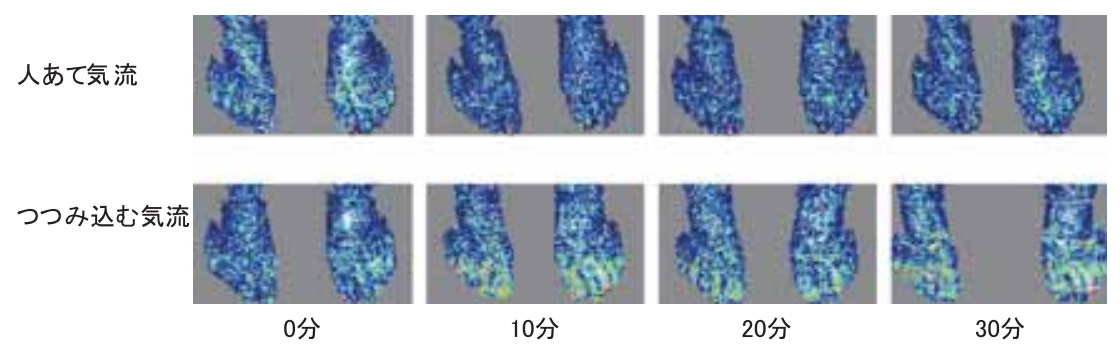

図 5 レーザ・ドップラ式血流計による血流画像 代表的な例として被験者 1 名の血流画像を示した.

表 1 歩行速度測定

\begin{tabular}{lllccll}
\hline & & 負荷後 & エアコン 30 分 & $\mathrm{d}$ (エアコン 30 分-負荷後) \\
\hline 歩行速度 & 人あて気流 & $149 \pm 21$ & $139 \pm 14$ & $-10 \pm 11$ & \\
$(\mathrm{~m} / \mathrm{min})$ & つつみ込む気流 & $140 \pm 31$ & $143 \pm 15$ & $3 \pm 24$ & $\mathrm{p}=0.166$ \\
\hline 歩行率 & 人あて気流 & $190 \pm 17$ & $182 \pm 20$ & $-8 \pm 14$ & \\
$(\mathrm{step} / \mathrm{min})$ & つつみ込む気流 & $178 \pm 38$ & $185 \pm 22$ & $7 \pm 36$ & \\
\hline 重複歩距離 & 人あて気流 & $1.57 \pm 0.15$ & $1.54 \pm 0.16$ & $0 \pm 0.13$ \\
$(\mathrm{~m})$ & つつみ込む気流 & $1.59 \pm 0.19$ & $1.56 \pm 0.20$ & $0 \pm 0.14$ & \\
\hline
\end{tabular}

平均値土標準偏差

対応のある $\mathrm{t}$ 検定

休息 30 分後の疲労負荷後 (エアコン休息 0 分後) からの 変化量に打いて, 歩行速度の低下抑制傾向が認められた。

\section{4. 生化学的検査}

結果を表 2 に示した。つつみ込む気流群は人あて気流 群と比較して，エアコン休息 30 分後に打いて，尿中 8イソプロスタン/クレアチニン比の有意な低下，尿中ホ モバニリン酸/クレアチニン比の低下傾向が認められ た. また，エアコン休息 30 分後の疲労負荷前からの変化 量において, 唾液アミラーゼの上昇抑制傾向が認められ た.

\section{5. 理学的検査}

結果を表 3 に示した。つつ久込む気流群は人あて気流 群と比較して, エアコン休息 30 分後に嗄いて体温の有意 な低下抑制が認められた。

\section{6. 疲労負荷時の作業パフォーマンス}

内田クレペリン検査抒よび ATMT の作業パフォーマ ンスに颃いて 2 群間で有意な差は認められず，同等の疲 労負荷量であることが確認された。

\section{7. 生活状況調査}

生活記録日誌に基づいて解析した睡眠時間, 就業時間, 運動量に扮いて 2 群間で有意な差は認められなかった。
また，試験期間において特記すべき生活環境の変化等は みられなかった。

\section{8. 温湿度の記録}

エアコンルーム内外の温湿度については，2 回の検査 日間で試験結果に影響を及ぼすと考兄られる差は認めら れなかった。

\section{9. 有害事象・副作用}

第 1 検査日の疲労負荷後に気分不良による 1 名の脱落 があったが，エアコンルームに入る前であり，試験機器 との因果関係はなかった。すべての被験者に扎いて，診 察・問診, 生活状況調查, 生化学的検查, 理学的検査の 結果から, 試験機器と因果関係があると考兄られる有害 な影響は認められなかった。

\section{考 察}

本試験では, デスクワークによる 2 時間の疲労負荷 後にェアコンルームで 30 分間休息した場合の, 人あて気 流に対するつつ久込む気流の健康維持および疲労に対す る効果について検討した.

VAS 検查による主観的評価から，つつ久込む気流群は 人あて気流群と比較して, 疲労感を軽減すること, 快適 感を上昇すること，末梢の冷えおよび膝関節の疼痛を抑 
表 2 生化学的検査

唾液検査

\begin{tabular}{|c|c|c|c|c|c|c|}
\hline & & 負荷前 & 負荷後 & & エアコン 30 分 $\mathrm{d}$ & (エアコン 30 分-負荷前) \\
\hline \multirow{2}{*}{$\begin{array}{l}\text { アミラーゼ } \\
(\mathrm{KU} / \mathrm{L})\end{array}$} & 人あて気流 & $51.5 \pm 15.6$ & $92.7 \pm 22.3$ & & $111.0 \pm 26.8$ & $59 \pm 25.8$ \\
\hline & つつみ込む気流 & $59.4 \pm 32.0$ & $95.1 \pm 35.2$ & & $109.5 \pm 41.4$ & $50 \pm 28.1$ \\
\hline \multirow{2}{*}{$\begin{array}{l}\text { コルチゾール } \\
(\mu \mathrm{g} / \mathrm{dL})\end{array}$} & 人あて気流 & $0.232 \pm 0.116$ & $0.184 \pm 0.097$ & & $0.182 \pm 0.079$ & $0 \pm 0.067$ \\
\hline & つつみ込む気流 & $0.262 \pm 0.113$ & $0.167 \pm 0.045$ & & $0.205 \pm 0.071$ & $0 \pm 0.107$ \\
\hline \multirow{2}{*}{$\begin{array}{l}\text { 総タンパク } \\
(\mu \mathrm{g} / \mathrm{mL})\end{array}$} & 人あて気流 & $680 \pm 226$ & $1237 \pm 536$ & & $1440 \pm 692$ & $760 \pm 554$ \\
\hline & つつみ込む気流 & $691 \pm 258$ & $1219 \pm 551$ & & $1357 \pm 543$ & $666 \pm 380$ \\
\hline \multirow{2}{*}{$\begin{array}{l}\text { クロモグラニン A } \\
(\mathrm{pmol} / \mathrm{mL})\end{array}$} & 人あて気流 & $4.747 \pm 6.156$ & $4.945 \pm 4.820$ & \multirow{2}{*}{$\mathrm{p}=0.012$} & $5.322 \pm 4.992$ & $1 \pm 1.952$ \\
\hline & つつみ込む気流 & $3.749 \pm 3.284$ & $8.546 \pm 7.065$ & & $8.095 \pm 6.651$ & $4 \pm 6.907$ \\
\hline
\end{tabular}

尿検査

\begin{tabular}{|c|c|c|c|}
\hline & & エアコン 30 分 & \\
\hline \multirow{2}{*}{$\begin{array}{l}\text { クレアチニン } \\
(\mathrm{mg} / \mathrm{dL})\end{array}$} & 人あて気流 & $116 \pm 57$ & \\
\hline & つつみ込む気流 & $181 \pm 62$ & \\
\hline \multirow{2}{*}{$\begin{array}{l}\text { 尿量 } \\
(\mathrm{mL})\end{array}$} & 人あて気流 & $109 \pm 68$ & \\
\hline & つつみ込む気流 & $59 \pm 23$ & \\
\hline \multirow{2}{*}{$\begin{array}{l}\text { バニルマンデル酸 } \\
(\mathrm{mg} / \mathrm{L})\end{array}$} & 人あて気流 & $4.5 \pm 2.4$ & \\
\hline & つつみ込む気流 & $6.7 \pm 1.6$ & \\
\hline \multirow{2}{*}{$\begin{array}{l}\text { ホモバニリン酸 } \\
(\mathrm{mg} / \mathrm{L})\end{array}$} & 人あて気流 & $5.2 \pm 2.7$ & \\
\hline & つつみ込む気流 & $6.9 \pm 1.9$ & \\
\hline \multirow{2}{*}{$\begin{array}{l}\text { 8-イソプラスタン } \\
(\mu \mathrm{g} / \mathrm{L})\end{array}$} & 人あて気流 & $1.066 \pm 0.388$ & \\
\hline & つつみ込む気流 & $1.471 \pm 0.429$ & \\
\hline \multirow{2}{*}{$\begin{array}{l}8-\mathrm{OHdG} \\
(\mu \mathrm{g} / \mathrm{L})\end{array}$} & 人あて気流 & $11.65 \pm 6.82$ & \multirow{2}{*}{$\mathrm{p}=0.032$} \\
\hline & つつみ込む気流 & $16.45 \pm 2.84$ & \\
\hline \multirow{2}{*}{$\begin{array}{l}\text { バニルマンデル酸／クレアチニン比 } \\
(\mu \mathrm{g} / \mathrm{mg})\end{array}$} & 人あて気流 & $3.8 \pm 0.7$ & \\
\hline & つつみ込む気流 & $3.9 \pm 0.7$ & \\
\hline \multirow{2}{*}{$\begin{array}{l}\text { ホモバニリン酸/クレアチニン比 } \\
(\mu \mathrm{g} / \mathrm{mg})\end{array}$} & 人あて気流 & $4.3 \pm 0.8$ & \multirow{2}{*}{$\mathrm{p}=0.056$} \\
\hline & つつみ込む気流 & $3.9 \pm 0.6$ & \\
\hline \multirow{2}{*}{$\begin{array}{l}\text { 8-イソプラスタン /クレアチニン比 } \\
(\mathrm{ng} / \mathrm{mg})\end{array}$} & 人あて気流 & $0.976 \pm 0.186$ & \multirow{2}{*}{$\mathrm{p}=0.036$} \\
\hline & つつみ込む気流 & $0.841 \pm 0.144$ & \\
\hline \multirow{2}{*}{$\begin{array}{l}\text { 8-OHdG/クレアチニン比 } \\
(\mathrm{ng} / \mathrm{mg})\end{array}$} & 人あて気流 & $9.61 \pm 2.72$ & \\
\hline & つつみ込む気流 & $9.88 \pm 3.01$ & \\
\hline
\end{tabular}

平均值士標準偏差

対応のある検定

8-OHdG: 8-ヒドロキシデオキシグアノシン

表 3 理学的検查

\begin{tabular}{|c|c|c|c|c|c|}
\hline & & 負荷前 & 負荷後 & エアコン 30 分 & \\
\hline \multirow{2}{*}{$\begin{array}{l}\text { 脈拍 } \\
\text { (bpm) }\end{array}$} & 人あて気流 & $69.6 \pm 9.4$ & $66.3 \pm 7.2$ & $63.6 \pm 7.7$ & \\
\hline & つつみ込む気流 & $70.0 \pm 12.1$ & $68.4 \pm 9.5$ & $65.8 \pm 10.9$ & \\
\hline \multirow{2}{*}{$\begin{array}{l}\text { 収縮期血圧 } \\
(\mathrm{mmHg})\end{array}$} & 人あて気流 & $114.7 \pm 18.5$ & $109.9 \pm 19.2$ & $108.9 \pm 18.4$ & \\
\hline & つつみ込む気流 & $110.3 \pm 14.4$ & $105.4 \pm 14.2$ & $108.1 \pm 18.3$ & \\
\hline \multirow{2}{*}{$\begin{array}{l}\text { 拡張期血圧 } \\
(\mathrm{mmHg})\end{array}$} & 人あて気流 & $69.1 \pm 10.9$ & $64.4 \pm 13.8$ & $65.4 \pm 13.6$ & \\
\hline & つつみ込む気流 & $66.7 \pm 11.6$ & $61.6 \pm 13.3$ & $65.3 \pm 11.1$ & \\
\hline \multirow{2}{*}{$\begin{array}{l}\text { 体温 } \\
\left({ }^{\circ} \mathrm{C}\right)\end{array}$} & 人あて気流 & $36.4 \pm 0.3$ & $36.5 \pm 0.3$ & $36.1 \pm 0.2$ & \multirow{2}{*}{$\mathrm{p}=0.005$} \\
\hline & つつみ込む気流 & $36.5 \pm 0.3$ & $36.5 \pm 0.2$ & $36.5 \pm 0.1$ & \\
\hline \multirow{2}{*}{$\begin{array}{l}\text { 体重 } \\
(\mathrm{kg})\end{array}$} & 人あて気流 & $53.3 \pm 5.3$ & & & \\
\hline & つつみ込む気流 & $53.4 \pm 5.2$ & & & \\
\hline
\end{tabular}

平均值土標準偏差

対応のある $\mathrm{t}$ 検定 
制することが明らかとなった、レーザ・ドップラ式血流 計による血流測定に沶いては末梢血流の低下抑制が認め られ，疲労負荷により低下した末梢血流( ${ }^{(1)}$ の回復をつつ 久込む気流群が早める効果が認められた。 また，つつ及 込む気流群では体温の低下抑制効果が認められた。 これ らのことから，つつみ込む気流は体温低下を抑制し，そ れに伴い末梢毛細血管の収縮が抑制されて末梢血流が維 持されることにより，末梢の冷えを抑制したと考兄られ た.さらに, 歩行速度は膝関節の疼痛との相関が知られ ているが7)，つつみ込む気流群でその低下抑制傾向がみ られた，膝関節の疼痛を訴兄る人では末梢血流が低下し て打り，これを回復させることで関節痛が緩和すること が報告されている ${ }^{8,9}$. つつ夕込む気流の末梢血流維持効 果により膝関節の血流も維持され，膝関節の疼痛が抑制 されたと考兄られた．末梢の冷えおよび膝関節の疼痛が 抑制された結果，全体的な感覚として疲労感の軽減，快 適感の上昇が得られたと考兄られた。

生化学的な指標としては, つつ久込む気流群で尿中ホ モバニリン酸/クレアチニン比の低下傾向がみられた. ホモバニリン酸はドーパミンの最終代謝物であり交感神 経活動を反映する ${ }^{10)}$ ．唾液検查に沶いて子交感神経活動 を反映するアミラーゼ活性 ${ }^{11,12)}$ の上昇抑制傾向がみら れて扣り,つつ久込む気流が疲労負荷によって優位と なった交感神経活動13) 抑制（自律神経機能の乱れを調 節）したものと考兄られた。交感神経活動は，冷刺激に より亢進して血管収縮を引き起こし，末梢血流の低下を 誘発することが知られている14).つつ及込む気流の末梢 血流維持効果が，冷刺激軽減に上る自律神経機能の調節 作用に関与した変化でもあると考兄られた。 また，つつ 又込む気流群では尿中 8-イソプロスタン/クレアチニ ン比の低下がみられた８-イソプラスタンは活性酸素が リン脂質を過酸化することで生成し細胞の機能障害なぞ をもたらすが ${ }^{15)}$ ，疲労との関連も報告されている ${ }^{16)}$ 。つ つ久込む気流が疲労負荷による酸化ストレスの上昇 ${ }^{17) を ~}$ 抑制したものと考兄られ，これは末梢血流維持に起因し た作用である可能性が考兄られた。

主観的評価は日常生活により影響をらける可能性も考 えられるが，つつみ込む気流群と人あて気流群の間で生 活状況に差はみられず，本試験においては試験機器によ る効果の評価検討に影響を及ぼす外的要因は特に認めら れなかった。

以上のことから，疲労負荷後のつつ久込む気流制御工 アコンでの休息は，体温低下を抑制し，末梢血流を維持 することにより，末梢の冷え扣よび膝関節の疼痛を抑制 乙, 疲労感の軽減拈よび快適感の上昇を促進することが 明らかとなった。これまで人あて気流制御エアコンは,
健康に悪影響を及ぼす面もあったが，本試験におけるつ つ久込む気流制御エアコンでは健康への悪影響はみられ なかった。

\section{結 論}

つつ久込む気流制御エアコンでの休息は，体温低下を 抑制し，末梢血流を維持することにより末梢の冷えを抑 制した．同時に，膝関節の血流を維持することにより膝 関節の疼痛も抑制した。 さらにこれらの作用により, 疲 労感の軽減执よび快適感の上昇を促進することが明らか となった。 よって本研究により，つつ久込む気流制御工 アコンは健康維持和よび疲労に対して有用であることが 示された。

\section{謝 辞}

（株）総合医科学研究所の公募に応じ, 本試験にご参加 くださいました被験者の皆様に感謝いたします。

\section{助成源}

シャープ株式会社

\section{参 考 文 献}

1) 厚生労働省. 平成14年労働者健康状況調查. 厚生労働省統 計情報. 2003.

2）外岡豊彦監修. 内田クレペリン精神検查・基礎テキスト. 日本・精神技術研究所. 1975.

3) 梶本修身, 山下 仰, 高橋清武ら. Trail-Making-Test を改 良した「ATMT 脳年齢予測・痴呆判別ソフト」の臨床的有 用性一タッチパネルを用いた精神作業能力テストの開発 一. 新薬と臨林. 2000; 49: 104-115.

4) Maxwell C. Sensitivity and accuracy of the visual analogue scale: a psycho-physical classroom experiment. Br J Clin Pharmacol 1978; 6: 15-24.

5) 岩谷力監修. 変形性膝関節症の保存的治療ガイドブック改 訂版.メディカルレビュ一社. 2006.

6) Nilsen KB, Sand T, Stovner LJ, et al. Autonomic and muscular responses and recovery to one-hour laboratory mental stress in healthy subjects. BMC Musculoskel Dis 2007; 8: 81 .

7) 渡邊裕之, 占部 憲, 神谷健太郎ら。变形性膝関節症飞扮 ける Quality of life (QOL) と身体特性との関係一日本版㯲関 節症機能評価尺度 $(\mathrm{JKOM})$ を用いた評価一. 理学療法学 2007; 34: 67-73.

8) Näslund J, Waldén M, Lindberd LG. Decreased pulsatile blood flow in the patella in patellofemoral pain syndrome. Am J Sports Med 2007; 35: 1668-1673. 
9) Belcaro G, Cesarone MR, Dugall M, et al. Effects of shock waves on microcirculation, perfusion, and pain management in critical limb ischemia. Angiology 2005; 56: 403-407.

10) Frankenhaeuser M, Lundberg U, Rauste von Wright M, et al. Urinary monoamine metabolites as indices of mental stress in healthy males and females. Pharmacol Biochem Behav 1986; 24: 1521-1525.

11) Nater UM, Marca RL, Florin L, et al. Stress-induced changes in human salivary alpha-amylase activity-associations with adrenergic activity. Psychoneuroendocrinology 2006; 31: 49-58.

12) 井澤修平, 城月健太郎，菅谷 渚ら。唾液を用いたストレ ス評価一採取及び測定手順と各唾液中物質の特徵一. 日本 補完代替医療学会誌2007; 4(3): 91-101.
13) 山口浩二，笹部哲也，倉恒弘彦ら. 自律神経異常と疲労. 日本疲労学会誌2005; $1: 8$.

14) Kistler A, Mariauzouls C, von Berlepsch K. Fingertip temperature as an indicator for sympathetic responses. Int J Psychophysiol 1998; 29: 35-41.

15) Morrow JD, Hill KE, Burk RF, et al. A series of prostaglandin F2-like compounds are produced in vivo in humans by a noncyclooxygenase, free radical-catalyzed mechanism. Proc Natl Acad Sci USA 1990; 87: 9383-9387.

16) 田中雅彰, 鴫原良仁, 藤井比佐子ら. CBEX-Dr 配合飲料の 健常者に扫子る抗疲労効果. 薬理と治療2008; 36: 199-212.

17) Alessio HM. Exercise-induced oxidative stress. Med Sci Sports Exerc 1993; 25: 218-224.

\title{
ABSTRACT \\ Effect of Enveloping-airflow Air Conditioner on Health Maintenance and Fatigue in Healthy Women
}

\author{
Masahito NISHITANI ${ }^{1}$, Yukishige SHIRAICHI ${ }^{2}$, Masaki OHTSUKA ${ }^{2}$, Sayaka AOYAGI ${ }^{3}$, Tomohiro SUGINO $^{3}$, \\ Yoshitaka KAJIMOTO ${ }^{3}$, Osami KAJIMOTO ${ }^{4}$ \\ ${ }^{1}$ Soiken Clinic \\ ${ }^{2}$ Sharp Corporation \\ ${ }^{3}$ Soiken Inc \\ ${ }^{4}$ Osaka City University Graduate School of Medicine
}

Objective: In the present study, we investigated the effects of enveloping-airflow air conditioner on health maintenance and fatigue in healthy volunteers. The enveloping airflow is that of gently holding the whole room space along the ceiling, wall, and floor. Design: In a randomized placebo-controlled crossover trial, 10 healthy women who had feeling cold, stiff shoulder and knee pain very often under air conditioner working, participated in the study. They performed fatigue-inducing desk work for 2 hours, and rested for 30 minutes in the air conditioned room controlled by enveloping airflow or direct airflow.

Methods: We evaluated subjective sensation by Visual Analogue Scale (VAS), peripheral blood flow by laser-Doppler flowmetry, and body temperature.

Result: The enveloping airflow prevented hypothermia, increased blood flow, moreover attenuated feeling of cold, knee pain and fatigue, increased sensation of comfort as compared with the direct air flow.

Conclusion: Enveloping-airflow air conditioner is effective in maintaining health and attenuating fatigue.

Key words: enveloping airflow, air conditioner, health maintenance, fatigue, feeling of cold 